\title{
Review on Impact of Plant Breeding in Crop Improvement, Ethiopia
}

\author{
Desalegn Alemayehu \\ Post graduate student at Jimma University College of Agriculture and Veterinery Medicine, Department of \\ Horticulture and Plant Sciences, Jimma, Ethiopia
}

*Corresponding Author: Desalegn Alemayehu, Post graduate student at Jimma University College of Agriculture and Veterinery Medicine, Department of Horticulture and Plant Sciences, Jimma, Ethiopia

\begin{abstract}
In earlier days the extent of plant breeding as an art and as a science was much disputed. Plant breeding was practiced first when people learned to look for superior plants to harvest for seed; thus selection became the earliest method of plant breeding. The results of those primitive efforts in plant selection contributed much to the evolutionary development of each of the cultivated crops. The art of plant breeding lies in the ability of the breeder to observe differences that may have economic value in plants of the same species. Before breeders possessed the scientific knowledge that is available today, they relied largely on their skill and judgment in selecting the superior types. The breeders should be good observers, quick to recognize variations among plants of the same species, which could be used as the basis for establishing new varieties. Among the scientific disciplines essential to addressing this challenge, plant breeding will play a unique role by developing the new crops, ornamentals, or forest trees that meet societal needs. Plant breeders will develop plants that are adapted to our changing environment and that can improve environmental quality. The objective of this paper is to review the impact plant breeding in agriculture in general and in crop improvement, food security \& investment specifically. The achievements of plant breeders are numerous, and can be grouped into several major areas of impact - yield increase, enhancement of compositional traits, crop adaptation, and the impact on crop production systems. Plant breeding is not without negative side effects, the replacement of local landraces with improved and varieties of narrow genetic base results in genetic vulnerability and genetic erosion. The limitation of genetic diversity directly impact on the lack of input materials for new breeding programs.
\end{abstract}

Keywords: plant breeding; plant breeding impact; crop improvement; food security; investment

\section{INTRODUCTION}

Plant breeding is the art and the science of changing and improving the heredity of plants (Poehlman, 2013 Modern plant breeding is based on understanding and utilization of genetic principles. It presupposes knowledge of the botanical characteristics of the species, of plant diseases and their epidemiology, of insect pests that feed upon the different plant species, of physiological factors related to adaptation of plants, and of biochemical characteristics affecting utilization and nutritive value (Poehlman, 2013). Knowledge about the extent of genetic variability and patterns of agromorphological variation in local germplasm from a target region is an important prerequisite for efficient crop improvement (Bashir et al., 2014). Global food security demands the development of new technologies to increase and secure cereal production on finite arable land without increasing water and fertilizer use. The use of heterosis through hybrid breeding has produced tremendous economic benefits in worldwide crop production (Kempe et al., 2014).

Generally plant breeding has been a key science in improving crop production, with an estimated contribution to productivity increases of around $50 \%$ cited by (Raggi et al., 2017). The improvements made in field crops by plant breeding are numerous (Poehlman, 2013). The impact of plant breeding in crop improvement, food security and investment was cited throughout this text to illustrate the ways in which the important crop plants have been made more productive and safer to grow. Developing sustainable societies is the grand challenge of the coming century. More food, feed, fiber, fuel, and forest products necessary to meet basic human needs must be produced from less land, water, and nutrients. A growing population will require expanded landscaping and urban forests to 
moderate the environment and produce suitable living spaces. Among the scientific disciplines essential to addressing this challenge, plant breeding will play a unique role by developing the new crops, ornamentals, or forest trees that meet societal needs. Plant breeders will develop plants that are adapted to our changing environment and that can improve environmental quality (Brummer et al., 2011). The objective of this paper is to review the impact plant breeding in agriculture in general and in crop improvement, food security \& investment specifically.

\section{IMPACTS OF PLANT BREEDING IN CROP IMPROVEMENT}

The achievements of plant breeders are numerous, and can be grouped into several major areas of impact: - yield increase, enhancement of compositional traits, crop adaptation, stress and lodging resistance and the impact on crop production systems. The improvement of crop plants by alteration of traits using traditional plant breeding program is time consuming and labor intensive. Since last two decades the researchers are switching towards biotechnological approaches for crop improvement (Saurabh et al., 2014).

\subsection{Improve Crop (Plant)}

The improvements made in field crops by plant breeding are numerous (Poehlman, 2013). A very good example is the provision of high-yielding varieties with adequate grain quality is the principal objective of the wheat breeder. However, to permit potential high yield to be fully realized and maintained, disease must be controlled (Lupton, 2014). The applications of transgenic technology for wheat hybrid seed production become successful through application of transgenic technology for hybrid seed production in wheat (Kempe et al., 2014). Induced mutation is used with great success by different breeding programs for developing new cultivars. Through mutation breeding, several rice mutant lines have been successfully produced. For example SCS118 Marques is a new irrigated rice cultivar developed by Epagri and released for cultivation in Santa Catarina for the pre-germinated crop system. The cultivar has resistance to lodging, high yield potential and long grains with superior quality $(8,944 \mathrm{~kg} / \mathrm{ha})$ (Schiocche et al., 2014).

Morphological improvement and heterosis are the only two effective approaches to increase yield potential in rice breeding (Yuan, 2015). Increasing in yield potential is very limited without these two approaches. However, genetic engineering must be combined with favorable morphological characters and strong heterosis; otherwise, there will be no actual contributions to yield increase (Yuan, 2015). Through morphological improvement and the use of inter-sub specific (indica/japonica) heterosis, much progress in developing super hybrid rice varieties has been achieved (Yuan, 2017). In Ethiopia, until 2014, about 960 varieties were recommended or released for major agricultural crops (cereals (Wheat, barley, tef, maize and sorghum), legumes (haricot bean, chickpea, lentil and faba bean), oilseeds, industrial (cotton), tuber and roots) and horticultural (vegetables, fruit trees and aromaticspices, medicinal) crops (Atilaw et al., 2016) (Table 1).

Table1. Number of varieties released by public and private sector (selected crops)

\begin{tabular}{|l|l|l|l|l|}
\hline Crop(s) & Total & Private sector & Private sector (\%) & $\begin{array}{l}\text { No of varieties under EGS } \\
\text { production (2015) }\end{array}$ \\
\hline Cereals (6) & 319 & 29 & 9 & 99 \\
\hline Legumes (7) & 186 & 2 & 1 & 51 \\
\hline Oilseeds (5) & 85 & 17 & 20 & 13 \\
\hline Tuber crops (2) & 61 & 6 & 10 & - \\
\hline Vegetables (17) & 120 & 63 & 53 & - \\
\hline Fruit trees & 41 & 4 & 10 & - \\
\hline Condiments and Medicinal plants & 40 & 3 & 8 & - \\
\hline Cotton & 26 & 7 & 27 & - \\
\hline Forage and pasture & 33 & 1 & 3 & - \\
\hline Total & $\mathbf{9 1 1}$ & $\mathbf{1 3 2}$ & $\mathbf{1 4}$ & $\mathbf{1 6 3}$ \\
\hline
\end{tabular}

Source: $M O A N R, 2016$

\subsubsection{Yield Increase}

Plant breeding is vital to increase the genetic yield potential of all crops. Yields of major crops, for example, Chinese cereal production has increased steadily from 83.4 Mt in 1961 to $474.2 \mathrm{Mt}$ in 2009, 
accounting for $9.5 \%$ of total global cereal production in 1961 and $21.8 \%$ in 2009 . The net increase over this period is $390.8 \mathrm{Mt}$ with an annual growth rate of $3.7 \%$, which is substantially higher than the world mean growth rate in cereal production of $2 \%$ during the same period (Fan et al., 2011). A yield breakthrough in super-rice varieties has been rapidly realized with the great efforts of Chinese rice breeders since 2011. The current landmark variety of super-hybrid rice, Super-1000, was developed, with yield reaching $16.0 \mathrm{t}$ ha-1 in a 6.8-ha demonstration trial in Gejiu county, Yunnan province in 2015 (Yuan 2017).

As summarized in the following (table 2) starting from 2004/05 to 2013/14 the yields increases in general. Yields in cereals averaged 21.4 quintals per hectare ( $\mathrm{q} / \mathrm{ha}$ ) in 2013/14 and ranged from about $28 \mathrm{q} / \mathrm{ha}$ in maize to $13 \mathrm{q} / \mathrm{ha}$ in teff. Annual growth in yields averaged about 7 percent in all cereals, with specific average annual growth in barley, teff, wheat, sorghum, and maize yields standing at 4.8, 5.2, 5.9, 7.1, and 8.1 percent, respectively. Growth in cereal yields was faster relative to other crop groups. However, these yield increases are not totally due to the genetic potential of the new crop cultivars but also due to improved agronomic practices (e.g., application of fertilizer, irrigation). Crops have been armed with disease resistance to reduce yield loss. Lodging resistance also reduces yield loss resulting from harvest losses.

Table2. Crop yields (in quintals per hectare)

\begin{tabular}{|l|l|l|l|l|l|l|l|l|l|l|}
\hline Crop & $2004 / 05$ & $2005 / 06$ & $2006 / 07$ & $2007 / 08$ & $2008 / 09$ & $2009 / 10$ & $2010 / 11$ & $2011 / 12$ & $2012 / 13$ & $2013 / 14$ \\
\hline Cereals & 11.8 & 12.7 & 14.4 & 15.3 & 16.7 & 16.9 & 17.8 & 20.0 & 21.6 & 21.4 \\
\hline Pulses & 8.7 & 8.5 & 9.5 & 10.5 & 12.0 & 11.8 & 13.2 & 13.1 & 13.7 & 14.5 \\
\hline Oilseeds & 5.4 & 4.8 & 5.5 & 8.2 & 8.2 & 7.8 & 8.6 & 8.1 & 8.4 & 8.7 \\
\hline Vegetables & 57 & 47 & 43 & 50 & 51 & 54 & 58 & 68 & 64 & 63 \\
\hline Root crops & 98 & 78 & 75 & 86 & 87 & 88 & 97 & 92 & 163 & 151 \\
\hline Fruits & 47 & 86 & 83 & 67 & 67 & 73 & 68 & 79 & 70 & 60 \\
\hline
\end{tabular}

Source: Authors' computation using CSA annual reports (CSA Volume I 2005-2014).

\subsubsection{Enhancement of Compositional Traits}

Breeding programs committed to improving agronomic, compositional, and nutritional qualities extend globally and include renowned organizations such as the International Maize and Wheat Improvement Center (CIMMYT) headquartered in Mexic (Venkatesh et al., 2015). Breeding for plant compositional traits to enhance nutritional quality or to meet an industrial need are major plant breeding goals. High protein crop varieties (e.g., high lysine or quality protein maize) have been produced for use in various parts of the world. For example, different kinds of wheat are needed for different kinds of products (e.g., bread, pasta, cookies, semolina). Breeders have identified the quality traits associated with these uses and have produced cultivars with enhanced expression of these traits. Genetic engineering technology has been used to produce high oleic sunflower for industrial use, while it is also being used to enhance the nutritional value of crops (e.g., pro-vitamin A "Golden Rice"). The shelf-life of fruits (e.g., tomato) has been extended through the use of genetic engineering techniques to reduce the expression of compounds associated with fruit deterioration.

\subsubsection{Crop Adaptation}

Selection of plant varieties specifically adapted to regional production and end-use is an important component of building a resilient food system (Brouwer, 2016). The integration of genetic engineering with conventional plant breeding, within an interdisciplinary approach, will likely accelerate the development and adoption of crop cultivars with enhanced adaptation to climate change related stresses (Varshney et al., 2011). Formal crop breeding using landrace resources has a key role to play in climate change-adaption strategies (Hellin, 2014). The development and dissemination of climate-responsive germplasm may take several years because the process consists of several steps, including breeding, on-farm testing, release of varieties, and germplasm dissemination crop plants are being produced in regions to which they are not native, because breeders have developed cultivars with modified physiology to cope with variations, for example, in the duration of day length (photoperiod) (Hellin, 2014). Early maturing cultivars can be used to produce a full season crop in areas where adverse conditions are prevalent towards the end of the normal growing season (Keleman et al., 2013). In crops such as barley and tomato, there are commercial cultivars in use, with drought, cold, and frost tolerance. Improved varieties that crop breeders identify as superior to landraces under experimental conditions may actually yield substantially less under farmers' conditions because of genotype-by-environment interactions (Keleman et al., 2013). 


\subsubsection{Resistance to Lodging and Shattering}

Lodging is the bending or breaking over of grain before harvest. Lodging causes yield losses in small grains, soybeans, corn, sorghum, and other crops. The amount of lodging varies from year to year, and is influenced by the rain and windstorms prior to harvest and by damage from disease, insects, and other causes (John M, 2013). In cereals, the reduction of plant height has been the main target for improving lodging resistance. A very good example is the shorter length of the lower internodes; smaller inner Culm diameter and higher thickness of mechanical tissue in japonica rice improved stem strength has reduced lodging risk (Bashir et al., 2014).

\subsubsection{Resistance to Stress}

Next to productivity, improved environmental stress tolerance is essential to all breeding programs (Brummer et al., 2011). Crop varieties with increased tolerance to abiotic stresses, like heat, frost, soil acidity, aluminum-rich soils and drought stress, can play an important role in managing current climatic variability and adapting to climate change (Cairns et al., 2013; (Brummer et al., 2011). The development of climate-resilient germplasm is possible through a combination of conventional, molecular and, in some cases, transgenic breeding approaches (Cairns et al., 2013). The current findings coupled with technological developments in crop genomics and genetics set the stage for plant breeding in which herbivore induced defenses can be used to provide better crop resistance against insect attack (Tamiru et al., 2015) Wheat: Hybrids often display increased yield, enhanced yield stability, and improved abiotic and biotic stress resistance that result from heterosis (hybrid vigor) (Schnable and Springer, 2013). Recent large-scale phenotyping involving extensive collections of inbred lines and hybrids revealed that hybrids were superior to the mean of their parents for grain yield, susceptibility to frost, leaf rust, and Septoria tritici blotch (Gowda et al., 2012; Longin et al., 2013). Consistently higher grain yield stability for wheat hybrids compared with lines was observed in multiplication field trials (Muhleisen et al., 2014).

\section{IMPACT OF PLANT BREEDING ON CROP GENETIC DIVERSITY}

Plant breeding is not without negative side effects, the replacement of local landraces with improved and varieties of narrow genetic base results in genetic vulnerability and genetic erosion. One of the grand challenges facing society in the 21 st century is to produce sufficient nutritious food in the face of climate change, population growth, and rapid urbanization, and to do so in an environmentally sustainable manner (Roa et al., 2016), enormous advances have been made for improved systems to genotype and phenotype genetic resources, and these have profound implications for the utilization of genetic diversity of crops (McCouch et al., 2012). Genetic diversity may be expected to be low due to natural populations have become fragmented, resulting in small population sizes and consequent genetic drift (Weeks et al., 2011). For out crossing species that display inbreeding depression, rather than adhering to a strictly local protocol that may reflect the low genetic diversity common in small fragmented populations, adaptive potential may be better achieved with high-quality and genetically diverse seed (Breed et al., 2013).

More recently, the spread of modern, commercial agriculture and the introduction of new varieties of crops has been the main cause of the loss of genetic diversity (Allender 2011; Lopes et al., 2015). Genetic uniformity leaves a species vulnerable to new environmental and biotic challenges and causes heavy damage to the society. For example the Irish Potato Famine of 1846-50 took as many as one million lives from hunger and disease, and changed the social and cultural structure of Ireland in profound ways. The famine also caused emigration of between 1.5 and 2.0 Million Irish (Hammer and Teklu 2008). The catastrophic outbreak of coffee rust in 1970 caused great losses in Brazil with higher coffee world market prices as a consequence. Other examples include the coffee rust epidemic in Ceylon in the 1870s, the tropical maize rust epidemic in Africa in the 1950s and the blue mould epidemic on tobacco in the USA and Europe in the 1960s (Marshall, 1977). The intensive selection in the process of hybrid rye breeding program narrowed genetic diversity in rye (Dopierała et al., 2015; Targońska et al., 2016). The search for new genetic variability and enrichment of the existing variability are important approaches in modern cereal breeding (Liu et al., 2014). Traditional breeding methods were based on strong selection pressure and improved the diversity and caused genetic uniformity of cultivars (Broda et al., 2016). The limitation of diversity directly impact on the lack of input materials for new breeding programs. The low variability within $S$. cereale ssp. cereale causes considerable difficulties in the achievement of the breeding goals (Broda et al., 2016). Therefore, the 
breeding of new cultivars for better yield, resistant to diseases and pests or with the increased tolerance of environmental pressures is very difficult.

\section{IMPACT OF PLANT BREEDING IN FOOD SECURITY}

Increasing the production and productivity of the crop sub sector is one of the measures taken in Ethiopia to assure food security of more than 80 million people and escape from long-lived poverty persisted in the country. The success of crop production in China for example has impacted on both global food supply and on natural resource use and availability and both of these changes have received global recognition (Fan et al., 2011). This improvement can only be realized if modern technologies are utilized from which seed take the first priority due to its nature. However, in order as seed to be a key factor in agricultural productivity, it must be channeled into a system. Positive impacts on poverty reduction and lower food prices were driven in large part by crop germplasm improvements in CGIAR centers that were then transferred to national agricultural programs for adaptation and dissemination (Pingali, 2012). Improved crop varieties are a key output of agricultural research and have contributed to significant increases in agricultural production and productivity (Pingali, 2012).

The richness of national per capita food supplies in regard to the 52 measured crop commodities increased consistently over the past 50 year for all variables (Khoury et al., 2014). This increase in similarity brought national food supplies around the planet closer to a global standard composition. Between 1961 and 2009, homogeneity increased by 16.7\%, as measured by the mean change in similarity between each country and the global standard composition, with a maximum (singlecountry) change of $59.7 \%$. Likewise, mean among-country similarity increased by $35.7 \%$. East and Southeastern Asian as well as sub-Saharan African countries as regional groups displayed the greatest changes in composition toward the global standard from 1961-2009, in association with the greatest increases in measured crop commodity richness and decreases in dominance. In Ethiopia, the seed demand is increasing rapidly due to the agricultural development. Thus, securing the supply of quality seed and planting material of the most important food crops is the most effective way to sustain food security (Atilaw, 2010).

Based upon a limited number of global crop commodities and processed products has been associated with the rise in no communicable diseases, such as adult-onset diabetes, heart disease, and certain forms of cancer (Kearney, 2010). The problem of food security is larger than it has ever been, with more than 800 million people chronically hungry and millions more at risk (FAO, 2013). Despite progress in some parts of the world to reduce hunger, in other areas, particularly in Africa and the Middle East, the hungry population is growing. Even among plant scientists, there is a well-ingrained perception that there is enough food in the world, but that the problem is distribution. It is clear that "distribution" is complicated by the fact that most suppliers have little apparent interest in distributing food to the more than 800 million hungry people in the world (FAO, 2013). The broadest and most widely accepted definition of food security is that provided by the FAO, that is, as a "situation that exists when all people, at all times, have physical, social, and economic access to sufficient, safe, and nutritious food that meets their dietary needs and food preferences for an active and healthy life" (FAO, 2013). Neither the status of food security nor its achievability is uniform throughout the world, within individual countries, or over time.

\section{IMPACT OF PLANT BREEDING IN INVESTMENT}

The major impact of investment in crop improvement programs at international research centers were the declining in even more sharply than overall CGIAR budgets during the 1990s. The reduced breeding budget trends have recently been reversed by growing investment in regional breeding programs, and reinvestment in breeding programs operated by international research centers; in particular, this investment has come from the Bill and Melinda Gates Foundation (Lynam et al., 2010). Investment in research and development is subject to trends in both public and private sector contributions, as well as to effective partnerships among research and development institutions (Fischer, 2014). The research intensity for low and middle-income (developing) countries in 2008 averaged $0.54 \%$, which was equivalent to only about one-fifth of the intensity shown by high-income countries that year. (Fischer, 2014) there is good news in the final feature: agricultural research intensity has increased in the major developing countries Brazil, China and India, and in the rest of Latin America (Table.3), as these national governments begin to recognize its importance. 
Table3. Agricultural research intensity by regions and major countries

\begin{tabular}{|l|l|l|l|l|}
\hline Country or region & Number of Countries & $1981(\%)$ & $2000(\%)$ & $2008(\%)$ \\
\hline Sub-Saharan Africa & 45 & 0.74 & 0.56 & 0.60 \\
\hline China & 1 & 0.38 & 0.38 & 0.50 \\
\hline India & 1 & 0.22 & 0.39 & 0.40 \\
\hline Asia excluding China \& India & 24 & 0.35 & 0.39 & 0.32 \\
\hline Brazil & 1 & 1.15 & 1.86 & 1.52 \\
\hline Latin America & 27 & 0.77 & 0.32 & 0.91 \\
\hline W/Asia \& N/Africa & 13 & $\mathrm{Na}$ & 0.65 & 0.68 \\
\hline E/Europe \& Central Asia & 21 & $\mathrm{Na}$ & 0.28 & 0.51 \\
\hline Developing countries & 133 & 0.51 & 0.52 & 0.54 \\
\hline Developed countries & 46 & 1.52 & 2.63 & 3.04 \\
\hline
\end{tabular}

Source: Beintema et al. (2012)

\subsection{Seed Company}

Seeds are most important input for agricultural production and they carry important genetic information of which the desirable types can be expressed under appropriate environment. However, the benefits of good crop varieties cannot be realized without the availability of quality seed. Seed system in Ethiopia represents the entire complex organizational, institutional and individual operations associated with the development, multiplication, processing, storage, distribution, and marketing of seed in the country (Alemu, 2015). Farmers, particularly smallholder ones, are involved in multiple kinds of seed systems, which can guarantee them in obtaining the quantity and quality of seeds they need and to market their produce (Atilaw, 2010). Seed systems in Ethiopia can be divided into two broad types: the formal system and the informal system (Alemu, 2010). Both systems are operating simultaneously in the country and difficult to demarcate between the two. There is however, a fact that the formal system is the original source of improved seeds in the informal system. There is also a system that interact the two systems referred to as integrated seed system (Atilaw, 2010).

The major actors of the formal system are: National Agricultural Research Systems (NARS), Ministry of Agriculture (MoA), Ethiopian Seed Enterprise (ESE) and private seed companies specializing on specific crops like Pioneer. Recently, regional seed enterprises (RSE) were also established as public seed enterprises (such as Oromiya Seed Enterprise (OSE), Amhara Seed Enterprise (ASE), and Southern Nations nationalities and Peoples Region Seed Enterprise (SRSE) and entered into the formal system (Alemu, 2015). All actors have inter-dependent roles in the system and inefficiency of one actor will automatically affect negatively the performances of the rest of the actors. NARS (EIAR \& RARIs) is responsible for variety development and supply of initial seed, and ESE and RSEs are playing key roles in mass production of improved seeds. MoA is also involved in variety release, multiplication, certification, and distribution of seeds in the country. The fund of research operation was mainly concentrated on the of government. Seed multiplication by ESE focused mainly limited two cereal crops (wheat and maize) and annual supply of certified seed by the enterprise doesn't exceed 20,000 tons (Atilaw, 2010). Wheat and hybrid maize constitute about $85 \%$ of the total output of the enterprise.

Alemu (2015) reported that over the last five years (2005-2010), on average more than 12 million hectare of land are cultivated by the major food crops are: cereals, legumes, oilseeds, root crops and horticultural crops. In 2009/10 cropping season the total area covered by improved seeds was about 361,231 hectares. In the same season, the largest volume of improved seeds used was that of maize and wheat, which amounted to about 5,720 and 4,690 tons, which has covered the largest area under improved seeds cultivation estimated to be about 210,000 and 38,000 hectares, respectively.

\subsubsection{Public Sector}

The Federal Ministry of Agriculture and Regional Bureaus of Agriculture coordinate the public seed sector with an impact on both the research institutions and public seed enterprises A complex of organizations and institutions operate, each responsible for parts of the above mentioned components of the public seed value chain (Alemu, 2015) Variety development has long been the sole responsibility of the EIAR. Since research decentralization, RARIs have increasingly been commissioned to develop varieties suitable for their regions. Moreover, agricultural universities and 
colleges are contributing to variety research and development. The variety release mechanism is still controlled at a federal level. The EIAR and the RARIs produce breeder seed and parental lines; the EIAR and the ESE are responsible for pre-basic and basic seed supply (Bishaw et al., 2008). The role of private seed companies is still limited to the production of hybrid maize seed, while the ESE is the main public sector seed producer and supplier of other crops and varieties. BoARDs and some NGOs help small farmers with informal seed production and supply (Bishaw et al., 2008).

At Federal MoARD level there is one seed testing laboratory with a capacity of 5000 samples per year. There are no full pledge quality laboratories with required equipment and furniture in EIAR. The availability of these facilities varies from one center to the other. Some centers may have some of these facilities, but none has a complete set of facilities indicated above (Atilaw, 2010). In addition three RSA and 33 private seed growers have storage facilities with different amount of storage capacities. Most of the facilities are owned by the ESE but are not located strategically for serving small farmers throughout the country Table (4) below. The amount of seed testing per annual is very low which can affect the amount of improved seed to be disseminated lower.

\begin{tabular}{|l|l|l|}
\hline Institution/Location & $\begin{array}{l}\text { Seed testing laboratory } \\
\text { Annual capacity (samples) }\end{array}$ & Distance from Addis Ababa \\
\hline A. Ethiopian Seed Enterprise & 5,000 & \\
\hline Addis Ababa & 2,500 & $175 \mathrm{~km}$ SE of Addis Ababa \\
\hline Asela & 2,500 & $275 \mathrm{~km}$ SE of Addis Ababa \\
\hline Koffele & 2,500 & $275 \mathrm{~km}$ South of Addis Ababa. \\
\hline Awassa & 2,500 & $330 \mathrm{~km}$ West of Addis Ababa \\
\hline Nekempt & 2,500 & $550 \mathrm{~km}$ North of Addis Ababa \\
\hline Bahir Dar & 2,500 & $790 \mathrm{~km}$ North of Addis Ababa \\
\hline Mekele & 20,000 & \\
\hline Sub_total & \\
\hline B. Regional Bureaus of Agriculture \\
\hline $\begin{array}{l}\text { Ambo, Assela, Axum, Dessie, } \\
\text { Durame, Durbete, Gondar, Markos, } \\
\text { Mekelle, and Wolaita }\end{array}$ & 25,000 & \\
\hline C. Federal Ministry of Agriculture & & \\
\hline Addis Ababa & 5,000 & \\
\hline Total & 50,000 & \\
\hline
\end{tabular}

Source: Abebe et al. (2012) and Bishaw et al., (2008)

\subsubsection{Private Sector}

Private seed companies (both domestic and international) are primarily concerned with the production, processing and marketing of hybrid maize seed. An increasing number of international seed companies are now entering the Ethiopian seed sector, introducing commercial varieties of potato, vegetables and hybrid maize. Most domestic companies are small or medium in size, and are locally oriented, but the production and marketing programs of international companies target the areas of high productivity, such as Amhara, Oromia and the Southern Nations, Nationalities and People's Region (SNNPR). Partnerships with public organizations, such as research institutes, Bureaus of Agriculture and some cooperatives, plays a significant role in variety demonstration, scaling-out farmer-based quality seed production and out-grower schemes. The scale of use of quality seed of improved varieties has increased over the last ten years (Alemu, 2015).

\subsubsection{NGO Sector}

NGOs programs was mainly to focus on intermediary systems with a community-based and local seed business approach. These NGOs support the establishment of primary cooperatives and unions for achieving local seed security, and consequently attaining food security. Other NGOs offer support for establishing community seed banks, and provide emergency or relief seed. NGOs and international development programs aim to improve the capacities of farmers' groups for producing and marketing seed, by organizing training and donating post-harvest technologies, such as seed cleaning machines. In some instances, NGOs have indefinitely secured the market for cooperatives and community-based producers, purchasing seed in bulk at fixed prices and then disseminating seed from its area of production to where it is needed by individual farmers for planting. The link to micro-financing 
institutes and/or commercial credit providers has not yet been well established, and access to finance remains a gap in the production of quality seed and availability of quality seed for purchase by farmers (Alemu, 2015).

\section{SUMMARY AND CONCLUSION}

Plant breeding is the art and the science of changing and improving the heredity of plants. It was practiced first when people learned to look for superior plants to harvest for seed; thus selection became the earliest method of plant breeding. The results of those primitive efforts in plant selection no doubt contributed much to the evolutionary development of each of the cultivated crops. Plant breeding is key science in improving crop production, with an estimated contribution to productivity increases of around 50\%. The improvements made in field crops by plant breeding are numerous. Among the scientific disciplines essential to addressing food insecurity, plant breeding will play a unique role by developing the new crops, ornamentals, or forest trees that meet societal needs. Plant breeders will develop plants that are adapted to our changing environment and that can improve environmental quality.

In Ethiopia, major achievements were made for major agricultural (cereals (Wheat, barley, tef, maize and sorghum), legumes (haricot bean, chickpea, lentil and faba bean), oilseeds, industrial (cotton), tuber and roots) and horticultural (vegetables, fruit trees and aromatic-spices, medicinal) crops. Until 2014, about 960 varieties were recommended or released. Plant breeding is not without negative side effects, the replacement of local landraces with improved and varieties of narrow genetic base results in genetic vulnerability and genetic erosion. The limitation of genetic diversity directly impact on the lack of input materials for new breeding programs.

Plant breeding also had a significant impact in investment and in addressing food security, which should be matched with the current the current large population of the world in general and Ethiopia in particular. The investment on seed system is more public in our country and dependent on government fund, but lower in private company as compared to public system. The capacity of quality seed distribution is lower, the farmers are forcing themselves to use in formal seed distribution among them. More the budget allocated over time in Ethiopia to handle important operation is lower. The plant breeding strategies to overcome important challenges in the country is or less affected.

\section{REFERENCES}

Abate, T., Fisher, M., Abdoulaye, T., Kassie, G.T., Lunduka, R., Marenya, P. and Asnake, W., 2017. Characteristics of maize cultivars in Africa: How modern are they and how many do smallholder farmers grow? Agriculture \& Food Security, 6(1), p.30.

Alemu, K., 2015. Seed Production and Dissemination Systems Analyses: The Case of Ethiopia. Seed, 35

Allender, C., 2011. The Second Report on the State of the World's Plant Genetic Resources for Food and Agriculture. Rome: Food and Agriculture Organization of the United Nations (2010), pp. 370, US \$95.00, ISBN 978-92-5-106534-1. Experimental Agriculture, 47(03), pp.574-574.)

Asfaw, A. and Blair, M.W., 2014. Quantification of drought tolerance in Ethiopian common bean varieties. Agricultural Sciences, 5(02), p.124.

Atilaw, A., 2010. A baseline survey on the Ethiopian seed sector. Submitted to the African Trade Association.

Atilaw, A., Alemu, D., Bishaw, Z., Kifle, T. and Kaske, K., 2016. Early generation seed production and supply in Ethiopia: Status, challenges and opportunities. Ethiopian Journal of Agricultural Sciences, 27(1), pp.99119 .

Bashir, E.M., Ali, A.M., Ali, A.M., Melchinger, A.E., Parzies, H.K. and Haussmann, B.I., 2014. Characterization of Sudanese pearl millet germplasm for agro-morphological traits and grain nutritional values. Plant Genetic Resources, 12(01), pp.35-47.

Breed, M. F., M. G. Stead, K. M. Ottewell, M. G. Gardner, and A. J. Lowe 2013. Which provenance and where? Seed sourcing strategies for revegetation in a changing environment. Conservation Genetics 14:1-10.

Broda, Z., Tomkowiak, A., Mikołajczyk, S., Weigt, D., Górski, F. and Kurasiak-Popowska, D., 2016. The genetic polymorphism between the wild species and cultivars of rye Secale cereale. History, 69(3), p.1652.

Brouwer, B.O., Murphy, K.M. and Jones, S.S., 2016. Plant breeding for local food systems: A contextual review of end-use selection for small grains and dry beans in Western Washington. Renewable Agriculture and Food Systems, 31(02), pp.172-184.

Brummer, E.C., Barber, W.T., Collier, S.M., Cox, T.S., Johnson, R., Murray, S.C., Olsen, R.T., Pratt, R.C. and Thro, A.M., 2011. Plant breeding for harmony between agriculture and the environment. Frontiers in Ecology and the Environment, 9(10), pp.561-568. 
Cairns, J. E., J. Hellin, K. Sonder, J. L. Araus, J. F. MacRobert, C. Thierfelder, and B. M. Prasanna. 2013. Adapting maize to climate change in sub-Saharan Africa. Food Security 5:345-360.

Cavanagh, C.R., Chao, S., Wang, S., Huang, B.E., Stephen, S., Kiani, S., Forrest, K., Saintenac, C., BrownGuedira, G.L., Akhunova, A. and See, D., 2013. Genome-wide comparative diversity uncovers multiple targets of selection for improvement in hexaploid wheat landraces and cultivars. Proceedings of the national academy of sciences, 110(20), pp.8057-8062.

da Silva Dias, J.C., 2015. Plant breeding for harmony between modern agriculture production and the environment. Agricultural Sciences, 6(1), p.87.

Dopierała P, Bujak H, Wilde P, Bajgain P, Dopierała A, Gordillo A, et al. Using inbred lines from ancient Polish population varieties to broaden genetic diversity in hybrid rye breeding. In: Proceedings of the International Conference on Rye Breeding and Genetics; 2015 Jun 24-26; Wrocław, Poland. Wrocław: Wydawnictwo Uniwersytetu Przyrodniczego we Wrocławiu; 2015. p. 44.

FAO, 2013. The State of Food Insecurity in the World 2013: The Multiple Dimensions of Food Security. Food and Agricultural Organization of the United Nations, Rome

Fischer, R.A., Byerlee, D. and Edmeades, G., 2014. Crop yields and global food security. ACIAR: Canberra, $\mathrm{ACT}$

Gowda, M., Longin, C.F.H., Lein, V. and Reif, J.C., 2012. Relevance of specific versus general combining ability in winter wheat. Crop Science, 52(6), pp.2494-2500.

Hammer K. and Teklu, Y., 2008. Plant genetic resources: selected issues from genetic erosion to genetic engineering. Journal of Agriculture and Rural Development in the Tropics and subtropics, 109(1), p.15.

Hellin, J., Bellon, M.R. and Hearne, S.J., 2014. Maize landraces and adaptation to climate change in Mexico. Journal of Crop Improvement, 28(4), pp.484-501.

Kearney, J., 2010. Food consumption trends and drivers. Philosophical transactions of the royal society B: biological sciences, 365(1554), pp.2793-2807.

Keleman, A., J. Hellin, and D. Flores. 2013. Diverse varieties and diverse markets: scale-related maize "profitability crossover" in the central Mexican Highlands. Human Ecol. 41:683-705.

Kempe, K., Rubtsova, M. and Gils, M., 2014. Split-gene system for hybrid wheat seed production. Proceedings of the National Academy of Sciences, 111(25), pp.9097-9102.

Khoury, C.K., Bjorkman, A.D., Dempewolf, H., Ramirez-Villegas, J., Guarino, L., Jarvis, A., Rieseberg, L.H. and Struik, P.C., 2014. Increasing homogeneity in global food supplies and the implications for food security. Proceedings of the National Academy of Sciences, 111 (11), pp.4001-4006.

Liu D, Zhang H, Zhang L, Yuan Z, Hao M, Zheng Y. Distant hybridization: a tool for interspecific manipulation of chromosomes. In: Pratap A, Kumar J, editors. Alien gene transfer in crop plants. Vol. 1. Innovations, methods and risk assessment. New York, NY: Springer; 2014. p. 25-42. http://dx.doi.org/10.1007/978-14614-8585-8_2

Longin, C.F.H., Gowda, M., Muhleisen, J., Ebmeyer, E., Kazman, E., Schachschneider, R., Schacht, J., Kirchhoff, M., Zhao, Y. and Reif, J.C., 2013. Hybrid wheat: quantitative genetic parameters and consequences for the design of breeding programs. Theoretical and applied genetics, 126(11), pp.27912801.

Lopes, M.S., El-Basyoni, I., Baenziger, P.S., Singh, S., Royo, C., Ozbek, K., Aktas, H., Ozer, E., Ozdemir, F., Manickavelu, A. and Ban, T., 2015. Exploiting genetic diversity from landraces in wheat breeding for adaptation to climate change. Journal of experimental botany, p.erv122.

Lupton, F., 2014. Wheat breeding: its scientific basis. Springer.

Marshall, D.R., 1977. The advantages and hazards of genetic homogeneity. Annals of the New York Academy of Sciences, 287(1), pp.1-20.

McCouch, S.R., McNally, K.L., Wang, W. and Hamilton, R.S., 2012. Genomics of gene banks: A case study in rice. American journal of botany, 99(2), pp.407-423.

Muhleisen, J., Piepho, H.P., Maurer, H.P., Longin, C.F.H. and Reif, J.C., 2014. Yield stability of hybrids versus lines in wheat, barley, and triticale. Theoretical and applied genetics, 127(2), pp.309-316.

Pingali, P.L., 2012. Green revolution: impacts, limits, and the path ahead. Proceedings of the National Academy of Sciences, 109(31), pp.12302-12308.

Poehlman, J.M., 2013. Breeding field crops. Springer Science \& Business Media.

Raggi, L., Ciancaleoni, S., Torricelli, R., Terzi, V., Ceccarelli, S. and Negri, V., 2017. Evolutionary breeding for sustainable agriculture: Selection and multi-environmental evaluation of barley populations and lines. Field Crops Research, 204, pp.76-88.

Roa, C., Hamilton, R.S., Wenzl, P. and Powell, W., 2016. Plant genetic resources: Needs, rights, and opportunities. Trends in Plant Science, 21 (8), pp.633-636. 
Saurabh, S., Vidyarthi, A.S. and Prasad, D., 2014. RNA interference: concept to reality in crop improvement. Planta, 239(3), pp.543-564.

Schiocchet, M.A., Noldin, J.A., Raimondi, J.V., Tulmann Neto, A., Marschalek, R., Wickert, E., Martins, G.N., Hickel, E., Knoblauch, R., Scheuermann, K.K. and Eberhardt, D.S., 2014. SCS118 Marques-New rice cultivar obtained through induced mutation. Crop Breeding and Applied Biotechnology, 14(1), pp.68-70.

Schnable, P.S. and Springer, N.M., 2013. Progress toward understanding heterosis in crop plants. Annual review of plant biology, 64, pp.71-88

Shiferaw, B., Kassie, M., Jaleta, M. and Yirga, C., 2014. Adoption of improved wheat varieties and impacts on household food security in Ethiopia. Food Policy, 44, pp.272-284.

Stolee, J.A., Shrestha, B., Mengistu, G. and Vertes, A., 2012. Observation of sub cellular metabolite gradients in single cells by lase rablation electro spray ionization mass spectrometry. Angewandte Chemie International Edition, 51(41), pp.10386-10389.

Tamiru, A., Khan, Z.R. and Bruce, T.J., 2015. New directions for improving crop resistance to insects by breeding for egg induced defence. Current Opinion in Insect Science, 9, pp.51-55.

Targońska M, Bolibok-Brągoszewska H, Rakoczy-Trojanowska M. Assessment of genetic diversity in Secale cereale based on SSR markers. Plant Mol Biol Report. 2016; 34(1):37-51. http://dx.doi.org/10.1007/ s11105-015-0896-4

Varshney RK, Bansal KC, Aggarwal PK, Datta SK, Craufurd PQ. Agricultural biotechnology for crop improvement in a variable climate: hope or hype? Trends Plant Sci. 2011; 16:363-371.

Venkatesh, T.V., Harrigan, G.G., Perez, T. and Flint-Garcia, S., 2015. Compositional assessments of key maize populations: B73 hybrids of the nested association mapping founder lines and diverse landrace inbred lines. Journal of agricultural and food chemistry, 63(21), pp.5282-5295

Weeks, A. R., C. M. Sgr_o, A. G. Young, R. Frankham, N. J. Mitchell, K. A. Miller, M. Byrne et al. 2011. Assessing the benefits and risks of translocations in changing environments: a genetic perspective. Evolutionary Applications 4:709-725.

Yuan, L.P., 2012. Conceiving of breeding further super-high-yield hybrid rice. Hybrid Rice, 27(6), pp.1-2.

Yuan, L.P., 2015. Hybrid rice achievements, development and prospect in China. Journal of Integrative Agriculture, 14 (2), pp.197-205.

Yuan, L., 2017. Progress in super-hybrid rice breeding. The Crop Journal.

Citation: D. Alemayehu, "Review on Impact of Plant Breeding in Crop Improvement, Ethiopia", International Journal of Research Studies in Agricultural Sciences (IJRSAS), vol. 3, no. 9, pp. 26-35, 2017. http://dx.doi.org/ 10.20431/2454-6224.0309005

Copyright: (C) 2017 Authors. This is an open-access article distributed under the terms of the Creative Commons Attribution License, which permits unrestricted use, distribution, and reproduction in any medium, provided the original author and source are credited. 